\title{
COVID 19 Disease: Effects on Health of Children
}

\author{
Dr.Mrunali Khandale, \\ Medical intern (MBBS) Jawaharlal Nehru Medical College ,Datta Meghe Institute of Medical Sciences, \\ Sawangi, Wardha, Maharashtra, India \\ E-mail :- mrunal94055@gmail.com
}

Type of manuscript :Review Article

Conflict of Interest: None

\begin{abstract}
:
COVID-19 disease outbreak was first reported in Wuhan china and was later reported to have spread throughout the world. As a global pandemic declared by WHO in march 2020 as of dated $24^{\text {th }}$ December infected patients are 74.4 million and recovered 44.3 million and deaths are 1.73 million. This is an global emergency which forced people to go into lockdown this lockdown helped to reduce the virus lode but it also caused many consequences like it affected children far from parents and families migrated for work because of restriction for social gathering all school, colleges, offices, industries are shut down this made peoples to lost their jobs and also give rise to trend of work from home and study from home entire education system is now online .according to UNICEF nearly 1.5 billion children out school and some $99 \%$ children are living with restriction on movement. this isolation has caused many disruption in daily routine of every single person not only economically poor but also economically sound are also suffered .some of the working peoples lost their job and those who travelled to metro cities lost their source of income and they have to leave these cities and return to their native places because of lockdown all the district borders are closed which land them in great trouble .also they don't have any transportation so most of the people travel by walking which made lots of adult and also children suffer because of dehydration and fatigue many suffered this also land in death of many migrants and this include some of the children this huge migration of people from their work place to villages made impact on minds of children they have to go through lot of trouble during this travel which may cause mental trauma for them and adjusting in new life in their village is difficult for them. Halted vaccination program has impacted child health and increase chance of vaccine preventable disease . children already suffering from diseases like mental diseases has lost access to physician this impacted adversely their treatment .also blood disorders in children who require regular blood transfusion are under danger during this pandemic . the pandemic has huge impact on health care system because of increased work strain this halted the pediatric health care .
\end{abstract}

KEY WORDS: global emergency ,children health ,mental trauma

\section{INTRODUCTION :}

There are more than 2 billion children all over the world who constitute $28 \%$ population of world(UNICEF 2019) and covid 19 pandemic affected these children mentally ,physically , socially, spiritually in many aspects. Global strategy to cope against pandemic is complete stop of human contact lead to closer of all school ,collage and playgrounds, parks etc it land people in imbalance of mental health and physical health as following -

- Death of loved ones due to COVID 19 affected mental health of child

- Restriction to physical activity of child
- Online education system

- Students studying away from parents under huge danger

- Domestic violence and child maltreatment

- School closer also caused cut down of mid day meal affecting nutrition of children

- Vaccination for children also affected

- Pediatric emergency care also affected

METHODS AND MATERIAL :

Data was obtained from following authors article and studies. Search included topics 
on "children mental health, children physical health in pandemic, vaccination ,pediatric emergency, domestric violence ,who data of covid 19 affected peoples ,UNICEF strategies to decrease mental stress in children "Google scholar search for related article and reference is given below for the same. Conducted a review and collected articles on children health and arrange them in given manner .interview of some parents and children is taken. some of questioners are asked to parents about their problems in parenting and their review is taken on lockdown situation .

Example

Questions asked to parents are :- what change they sow in their child after lockdown?

How was their experience in handling their child

How child studied from online lectures

Questions asked to children :-what problem they faced during online learning Was the environment in home playful during lockdown period

Did they face problems in communicating with their parents

The Indian government announced the lockdown on $24^{\text {th }}$ march and then extended to $3^{\text {rd }}$ may .This included complete lockdown of all the places where mass gathering of people is possible .This complete lockdown has impacted all the peoples of various age groups and various professions.

COVID 19 caused $1.73 \mathrm{M}$ deaths these are the sudden deaths person who was fit and fine yesterday is gone now which disturbs life of loved ones but this may cause on little ones who doesn't understand what happened to them children who are depend on their parents suffer more this may cause severe mental breakdown people with small families suffer more because of child only have one or two care givers .loss of one is very disturbing for a child (1) .also those children who have single parent and if he got isolated or quarantine this is inconvenient for child. And small one can't understand where they gone this may cause child to think that their parents doesn't love them which is cause of anxiety or depression it is reason for mental disturbance in a child .loss of care giver has serious negative effects on mental health have been documented also child become orphan and has to suffer like child abuse and malnourishment due to poor feeding. Child has to live with the grief and guilt of loss of their parents. It is cause of depression ,anxiety, panic disorders and phobias in adults who underwent a traumatic experiences in childhood . children's of frontline workers like police ,health workers and daily need suppliers are under huge risk of getting infection and also set children in great fear of loosing their loved ones impacting on their mental health and also increases chances of them to get infected. According to studies it states that most of the mental diseases and mental health issues are due to mental trauma during childhood so it is very important to help a child to go through these situation and this is possible by understanding their worries and solving them and assuring a child about their safety and their parents safety.

Online learning has its own disadvantages and because of this lockdown schools are closed all over the world. And this originates the fashion of online learning it is applied to all the children and teenagers they have to attain online lectures and also their homework is online. Some of the students gave their exams online which increase the chances of cheating students adapted various tricks to solve exam this may affect their post lockdown study.(2)in online learning a child can not interact with other students and teachers it only restricted to a one person who is teaching him and this is not good for early ages of learning because this is the age where child develop communication skills and learning through various group activity may researchers discourage online lectures 
in early age . online learning require more work that is great amount of reading and more assignments than traditional way of learning this is boring for students and this is not possible for a child to study daily for hrs from computers and phone it decreases their concentration and made learning difficult . online lectures require intense desire of learning in child and self discipline to complete all assignments and watch all lectures it requires self motivation for this parents and teachers should appreciate the child for completion of assignments. Also in traditional way of learning face to face interaction gives a immediate feedback to student which is not possible in online learning system. Those students who are poor in learning gets extra attention when it comes to traditional way of learning but due to low communication between teacher and student it is not possible. Online learning can cause social isolation because of loss of contacts with friends and relatives ,and increase time of learning from online platforms may rise the chance of child to face depression like problems.

Due to lockdown children can't go to school(3) can't play outside and can't meet their friends or relatives which increase their physical inactivity and affected social communication which is very important for a child to become a good person in all aspects like health and socially . loss of communication can be the reason of social isolation and affect the mental health of a child . some of the children started spending time by other non useful or distracting ways like watching TV and playing video game and watching online videos or movies this has many side effects like ophthalmic problems like blurred vision and headaches, dry eyes and symptoms of eyestrain(4) also playing video games(5) has raised the chances of offensive behaviors also watching adult stuff on online platforms is dangerous for children .so children should encouraged to talk to their friends via video calls and try to keep them in contact with others by arranging some activities among their friends like giving some task and awarding the best one also help in developing hobbies in children. Physical activity is requires for building muscles and growing bones in child and decrease activity leads to various diseases. Physically active child has stronger bones and lean body it also decrease the risk of diabetes type 2 , low body weight, lower levels of cholesterol and decrease chance of hypertension . loss of physical activities(6) affect child's health make them lazy can develop obesity and other health problems .physical activity like playing is very essential for child to grow and its development reduced activity in children can lead to many problems .so parents should try to engage them in activities which make them physically active .parents can teach them to dance this can also act as a mood changer dancing gives a joy and happiness to child yoga also helps to keep child healthy and pranayam(7)also helps to calm child and maintain concentration . exercising regularly is good habit to develop in a child(8).indoor games are good option for children parents should play these games it helps to increase bonding between children and parents .adolescents who are locked in home and loss of their privacy increase the stress and also many child show behavioral changes some studies shows the increase rate of addiction and in adolescents to reduce stress. parents should give some privacy to the children and also keep them happy and joyful .parents should try to solve all problems of adolescents .(9)

Many of the students prefer to complete their education from good universities in different countries. Lots of student in abroad are staying alone far from their parents but because of easy availability of travel across countries made this easy for them to study there. But during this pandemic it is difficult for travel across country land them in trouble this feeling 
of being away from family during this situation is very sad and may cause emotional breakdown of these students. So parents should try to communicate with them regularly via video calling and assure their safety try to solve their problems and make them feel safe. Student who study abroad are under great fear because of sudden closer of boundaries. Outsiders in many country are restricted to travel across countries and during this lockdown sudden closer of college campus and schools they don't have place to stay this is inconvenient for them to live in this situation for this government should provide funds and arrange places to stay for them

During this lockdown all places where couples and all family members can go and have fun time like parks , cinema halls , shopping molls, restaurants are closed and this made them to force to do same things repeatedly made them bored and frustrated. And even small things of partner made troublesome to other. Due to restriction of movements many couples facing problems due to loss of privacy and freedom also loss of jobs of various people increase economical stress on married couple(10) increase domestic violence. This has very bad impact on child mental health.children who grow in such background shows higher rate of post traumatic symptoms. Also it influence the child brain they can't understand how to respect others and it hampers their personality .(11) There is significant increase in domestic violence all over the world. In India most of the population residing in metropolitan city both the partners have job and they don't stay home whole day and the children have their school, but due to lockdown and closer of school and work from home for all the corporate peoples they have to stay home which was new foe them and this made the couple's to be with their partner $24 \mathrm{hr}$ and during this time they experience many new things which may be troublesome and raised the chances of misunderstanding and miscommunication leads to disputes in them and increase rate of divorce and domestic violence.Children in this background feel feared and it is not appropriate for mental development of child these violent acts in childhood may impact adversely on growing child. a child may suffer from anxiety and panic disorders .also increase stress and frustration in parents has increase the violence against child .physical, mental, and sexual violence is reported against child during this lockdown .lack of access to child protection authority also increase the burden. So to decrease these events child protection authority should work hard and government should implement some strict acts.(12)

$65 \%$ population of India reside in rural area and most of this population is depend on agriculture. During this period of pandemic all the markets where these people can sell their crops and buy are closed this has made huge impact on rural economy(13) . and about $75 \%$ children of India is from rural area this disturbance in rural economy has direct impact on families and also on the children in their family. India in village has affected very badly during this pandemic. Daily wage laborer are in great worry because of loss of job and work loss land them in economical stress lots of people don't have any kind of saving for this kind of emergency this land them in situation like hunger and the children of this household are affected more they are suffered from malnutrition because in growing age children require various nutritional food in many village children get their nutrition from school and anganwadi. Children in rural areas where online lectures is foreign thing for them and it is really not possible for these children to complete their studies because of poor connectivity of internet services. and poor knowledge about the online lectures . also most of the poor child can not afford to buy a cell phone or a 
laptop for his studies .this cause most of the students to stop their studies and increase the school dropouts rate. Children in villages have habit of studying from live classes and most of them understand things only this way and this lockdown situation made them to learn poorly this affected the all school going children. Closer of schools in rural area has land many children in huge worry because many children in our country get their lunch in school for free which is very essential for these child's nutritional state and growth also . Because of cut down of mid day meal which is very important for economically poor children this affected their nutrition and health and in many schools government arrange vaccination programs these programs are adversely affected during this lockdown

Vaccination for Children under age 5 is very important to protect them from many diseases according to national immunization schedule every children gets the vaccination for diseases like tuberculosis, mumps, measles , rubella , diphtheria, hepatitis $b$,tetanus etc but during this lockdown period it was difficult for parents to reach to primary health centers and other places for vaccination this lead to suffer the children can increase the risk of diseases which can be prevented by vaccination . due to shift of government focus on natural disaster due to virus has affected the ongoing vaccination programs .health care workers are totally focused on treatment and prevention of this pandemic and in India where shortage of health care system and workers can not give attention on these vaccination programs this temporary halted vaccination program increase risk of vaccine preventable disease breakdown (14)

During lockdown many of the hospitals closed their opd clinics to reduce the risk of viral spread but this land many peoples in trouble those patients who require regular follow up can't reach to physician.
Children with congenital diseases who required surgery are also suffered because of closer of ot of many hospitals .also the child with blood diseases like thalassemia and sickle cell anemia require regular blood transfusion can't arrange blood and many of them face trouble for admitting in hospital .many hospitals screen patients for covid 19 and then admit in hospital so the time span for which patients are getting screened doesn't get the proper treatment . this affected many emergency cases. Pediatric emergency (15)are also affected due to less number of health care authority as medical system is focused on serious and immediate risk of death patients, less sick patients who can be treated at homes have received less focused attention .different type of health services are given via telephone and videos. This helps to decrease the heath care burden but this also has its own disadvantages like inadequate physical examination and treatment is only based on history given by patients (16).

According to NATIONAL INSTITUTE OF MENTAL HEALTH AND NEURO SCINCES following some simple strategies are given (17)

"PROVIDE ASSURENCE WHENEVER NEEDED -it is important to reassure your children. Listen to their concerns and try to answer them their queries related to the outbreak .

MANGE CHILD ANXIETY -it is normal for child to become anxious at this time look out for emotional cues in child and talk to them avoid being judgmental when they express their feelings make them understand things better

ENGAGE THEM IN INDOOR ACTIVITIES- during this time, children may get easily bored. Involve them in indoor games to cut down boredom. You can also make their learning fun by giving them puzzles to solve and teaching them crafts .encourage them to pick up hobby. Involve child in some stretching exercises, yoga, or dancing which they will enjoy. 
You can also involve them in doing some simple household activities to keep them engage.

KEEP THEM IN CONTACT WITH THEIR FRINDS -physical distancing from friends can be a cause of distress for child. Encourage them to talk to their friends, cousins and loved ones by calling them up or through video calls you can also involve them in fun activities with their friends .

GIVE THEM CLEAR INFORMATION it is important to give them correct information about what is happening around the world this may increase anxiety so you can use picture and drawings for explanations

MAKE A ROUTINE OF LEARNING AT HOME -at this time when schools are closed, this should not stop child from learning .ensure that they have regular habit of learning by giving them small assignments to understand their progress ."

\section{DISCUSSION :}

Lockdown increase the chances of mental health disturbances in children and also increase the risk of malnourishment in children (18-20). Due to halted vaccination program increased chances of diseases in children .Online lectures and increased online activities of child impacted adversely on their growth and development(21-24). There is significant increase in child abuse and violence against children because of increase in domestic violence many children suffering from mental disturbances. Children in rural area faced problems in online learning. Children with congenital and various diseases are gone through trouble for proper treatment.Because of medical emergency many children with mild symptoms not attained properly. Lots of school going children who rely on mid day meal skims are suffered due to closer of school. Also the increased economical stress on family affected children nourishment and health.

\section{CONCLUSION :}

Covid 19 pandemic affected parents and children by various means as above stated lockdown has impacted adversely on children mental health and physical health too .government should consider all these things and take some actions to minimize it also parents should interact with children and try to understand their problems and solve them .parents have to implement some measures to develop a child into a good person socially and mentally food and essentials are provided by various social workers and government authority to decrease the risk of malnutrition in children to decrease the strain on pediatric health system should increase the required number of health workers and essentials in health system . government authority should provide proper funding in children health measures .also heath care services should be available via telephone .

\section{REFERENCES:}

[1] Nader KO. Childhood traumatic loss: The interaction of trauma and grief. Death and trauma: The traumatology of grieving. 1997:17-41.

[2] Dong C, Cao S, Li H. Young children's online learning during COVID-19 pandemic: Chinese parents' beliefs and attitudes. Children and youth services review. 2020 Nov 1;118:105440

[3] Phelps C, Sperry LL. Children and the COVID-19 pandemic. Psychological Trauma: Theory, Research, Practice, and Policy. 2020 Aug;12(S1):S73.

[4] Rawal V, Kumar M, Verma A, Pais J. COVID-19 Lockdown: Impact on Agriculture and Rural Economy. Society for Social and Economic Research. 2020.

[5] Kuss DJ, Griffiths MD. Online gaming addiction in children and adolescents: A review of empirical research. Journal of behavioral addictions. 2012 Mar 1;1(1):3-22. 
[6] Twisk JW. Physical activity guidelines for children and adolescents. Sports medicine. 2001 Jul 1;31(8):617-27

[7] Mukundananda S. Healthy Body Healthy Mind: Yoga for Children. JagadguruKripalujiYog; 2014 Apr 11.

[8] Mitra R, Moore SA, Gillespie M, Faulkner G, Vanderloo LM, ChulakBozzer T, Rhodes RE, Brussoni M, Tremblay MS. Healthy movement behaviours in children and youth during the COVID-19 pandemic: Exploring the role of the neighbourhood environment. Health \& place. 2020 Sep 1;65:102418.

[9] Guessoum SB, Lachal J, Radjack R, Carretier E, Minassian S, Benoit L, Moro MR. Adolescent psychiatric disorders during the COVID-19 pandemic and lockdown. Psychiatry Research. 2020 Jun 29:113264

[10] Wu M, Xu W, Yao Y, Zhang L, Guo L, Fan J, Chen J. Mental health status of students' parents during COVID19 pandemic and its influence factors. General Psychiatry. 2020;33(4)

[11] Vostanis P, Graves A, Meltzer H, Goodman R, Jenkins R, Brugha T. Relationship between parental psychopathology, parenting strategies and child mental health. Social psychiatry and psychiatric epidemiology. 2006 Jul 1;41(7):50914

[12] Fegert JM, Vitiello B, Plener PL, Clemens V. Challenges and burden of the Coronavirus 2019 (COVID19) pandemic for child and adolescent mental health: a narrative review to highlight clinical and research needs in the acute phase and the long return to normality. Child and adolescent psychiatry and mental health. 2020 Dec;14:1-1.

[13] Rawal V, Kumar M, Verma A, Pais J. COVID-19 Lockdown: Impact on
Agriculture and Rural Economy. Society for Social and Economic Research. 2020.

[14] Ali I. Impact of COVID-19 on vaccination programs: adverse or positive? Human Vaccines \&Immunotherapeutics. $2020 \quad$ Sep 6:1-7.

[15] Walker DM, Tolentino VR. COVID19: The impact on pediatric emergency care. Pediatric emergency medicine practice. 2020 Jun 5;17(Suppl 6-1):1-27.

[16] Kramer V, Papazova I, Thoma A, Kunz M, Falkai P, SchneiderAxmann T, Hierundar A, Wagner E, Hasan A. Subjective burden and perspectives of German healthcare workers during the COVID-19 pandemic. European archives of psychiatry and clinical neuroscience. 2020 Aug 19:1-1.

[17] Holt S, Buckley H, Whelan S. The impact of exposure to domestic violence on children and young people: A review of the literature. Child abuse \& neglect. 2008 Aug 1;32(8):797-810.

[18] Jameel, P.Z., and A.M. Taksande. "COVID-19: A Review of Drugs and Therapies for Children." Sri Lanka Journal of Child Health 49, no. 3 (2020): 210-17. https://doi.org/10.4038/sljch.v49i3.9 136.

[19] Lohiya, S.B., S. Damke, and R. Chaudhary. "Coronavirus Disease (COVID) 2019 in Children - A Short Review." International Journal of Current Research and Review 12, no. 17 (2020): 172-77. https://doi.org/10.31782/IJCRR.2020 .121726 .

[20] Mujbaile, N.S., and S. Damke. "The Impact of COVID 19 on Pregnant Women and Child Health." International Journal of Research in Pharmaceutical Sciences 11, no. Special Issue 1 (2020): 1367-73. 
https://doi.org/10.26452/ijrps.v11iSP L1.3645.

[21] Rana, N., and S. Borage. "Utility of Vaccination Adopted in India Forchildren to Fight against COVID19." International Journal of Research in Pharmaceutical Sciences 11, no. Special Issue 1 (2020): 45254.

https://doi.org/10.26452/ijrps.v11iSP L1.2810.

[22] Lakhkar, B.B., B. Guru, S. Damke, and S. Damke. "Most Susceptible Duo in COVID-19 Crisis: A Literature Review." Perinatology 21, no. 3 (2020): 112-23.

[23] Khatib, M., A. Sinha, A. Gaidhane, P. Simkhada, P. Behere, D. Saxena, B. Unnikrishnan, A. Khatib, M. Ahmed, and Q.S. Zahiruddin. "A Systematic Review on Effect of Electronic Media among Children and Adolescents on Substance Abuse." Indian Journal of Community Medicine 43, no. 5 (2018): S66-72. https://doi.org/10.4103/ijcm.IJCM_1 16_18.

[24] Meshram, K., A. Mourya, M. Hinge, L. James, and P. Mankar. "Effectiveness of Planned Teaching on Knowledge and Practice Regarding Growth Monitoring of Under-Five Children among Anganwadi Workers in the Rural Area of Wardha District." International Journal of Current Research and Review 12, no. 23 (2020): 20-24. https://doi.org/10.31782/IJCRR.2020 .122310 . 